\title{
Aloe maculata All. (Asphodelaceae) in the Free State Province, South Africa, and resurrection of 'var. ficksburgensis'
}

\author{
Gideon F. Smith ${ }^{1,2,4}$, Estrela Figueiredo ${ }^{3,4}$, Ronell R. Klopper ${ }^{1,2}$ and Neil R. Crouch ${ }^{5,6}$ \\ ${ }^{1}$ Biosystematics Research \& Biodiversity Collections, South African National Biodiversity Institute, \\ Private Bag X101, Pretoria 0001, South Africa (email: G.Smith@sanbi.org.za; R.Klopper@ sanbi.org.za). \\ 2 H.G.W.J. Schweickerdt Herbarium, Department of Plant Science, University of Pretoria 0002, Pretoria, \\ South Africa. \\ ${ }^{3}$ Department of Botany, P.O. Box 77000, Nelson Mandela Metropolitan University, Port Elizabeth 6031, \\ South Africa (email: estrelafigueiredo@ hotmail.com). \\ ${ }^{4}$ Centre for Functional Ecology, Departamento de Ciências da Vida, Universidade de Coimbra, 3001-455 \\ Coimbra, Portugal. \\ ${ }^{5}$ Ethnobotany Unit, South African National Biodiversity Institute, P.O. Box 52099, Berea Road 4007, \\ South Africa. \\ ${ }^{6}$ School of Chemistry, University of KwaZulu-Natal, Durban 4041, South Africa \\ (email: N.Crouch@sanbi.org.za).
}

Summary: Although morphologically variable and widely distributed in southern Africa, Aloe maculata All. is well defined by a suite of characters that includes maculate (spotted) leaves, flattopped inflorescences and uniformly coloured flowers. Being a predominantly mild-climate species, it rarely ventures into the more severe southern African interior escarpment, where one of its variants, var. ficksburgensis Reynolds - to date only validly published in combination with the name Aloe saponaria (Aiton) Haw. - occur. We here make the new combination at subspecific level, A. maculata subsp. ficksburgensis (Reynolds) Gideon F.Sm. \& Figueiredo, and record its occurrence near Winburg in central South Africa, about $80 \mathrm{~km}$ west of previously known records.

Zusammenfassung: Obwohl die im südlichen Afrika weit verbreitete Aloe maculata All. morphologisch variabel ist, ist sie gut durch eine Kombination von Merkmalen charakterisiert, u.a. die gefleckten Blätter, die flachgipfeligen Blütenstände und die einheitlich gefärbten Blüten. Die Art ist vorwiegend in milden Klimaten heimisch und kommt nur selten bis in das innere Escarpment des südlichen Afrikas vor, wo eine ihrer Varianten, var. ficksburgensis Reynolds - bis heute gültig nur als Kombination mit dem Namen Aloe saponaria (Aiton) Haw. publiziert - zuhause ist. Wir publizieren hier die neue Kombination auf der Rangstufe der Unterart, A. maculata subsp. ficksburgensis (Reynolds) Gideon F.Sm. \& Figueiredo, und berichten über ihr Vorkommen nahe Winburg im zentralen Südafrika, c. $80 \mathrm{~km}$ westlich der bisher bekannten Nachweise.

\section{Introduction}

Aloe maculata All. is widely distributed in southern Africa, where it is one of the most common species of Aloe L. Although quite variable, it is defined by a suite of morphological characters: it has maculate (spotted) leaves, inflorescences of between $0.4 \mathrm{~m}$ and $1.0 \mathrm{~m}$ tall, with flat-topped, densely capitate (head-shaped) racemes, and uniformly coloured flowers of $35-45 \mathrm{~mm}$ long. The species occurs from the Cape Peninsula in the Western Cape eastwards along the climatically moderate southern African coastal belt generally remaining below the Great Escarpment, to as far north and northeast as KwaZulu-Natal, Mpumalanga, Limpopo and Swaziland. However, it is unknown from adjacent Mozambique, and specimens from Zimbabwe, previously regarded as belonging to A. maculata, at the time as Aloe saponaria (Aiton) Haw., have been given recognition at the species rank as A. collina S.Carter (1996, 2001).

Reynolds (1937, 1950) regarded specimens of A. maculata from South Africa's Free State province and Lesotho as mostly, but not exclusively, belonging to the var. ficksburgensis Reynolds, under A. saponaria, the name then 

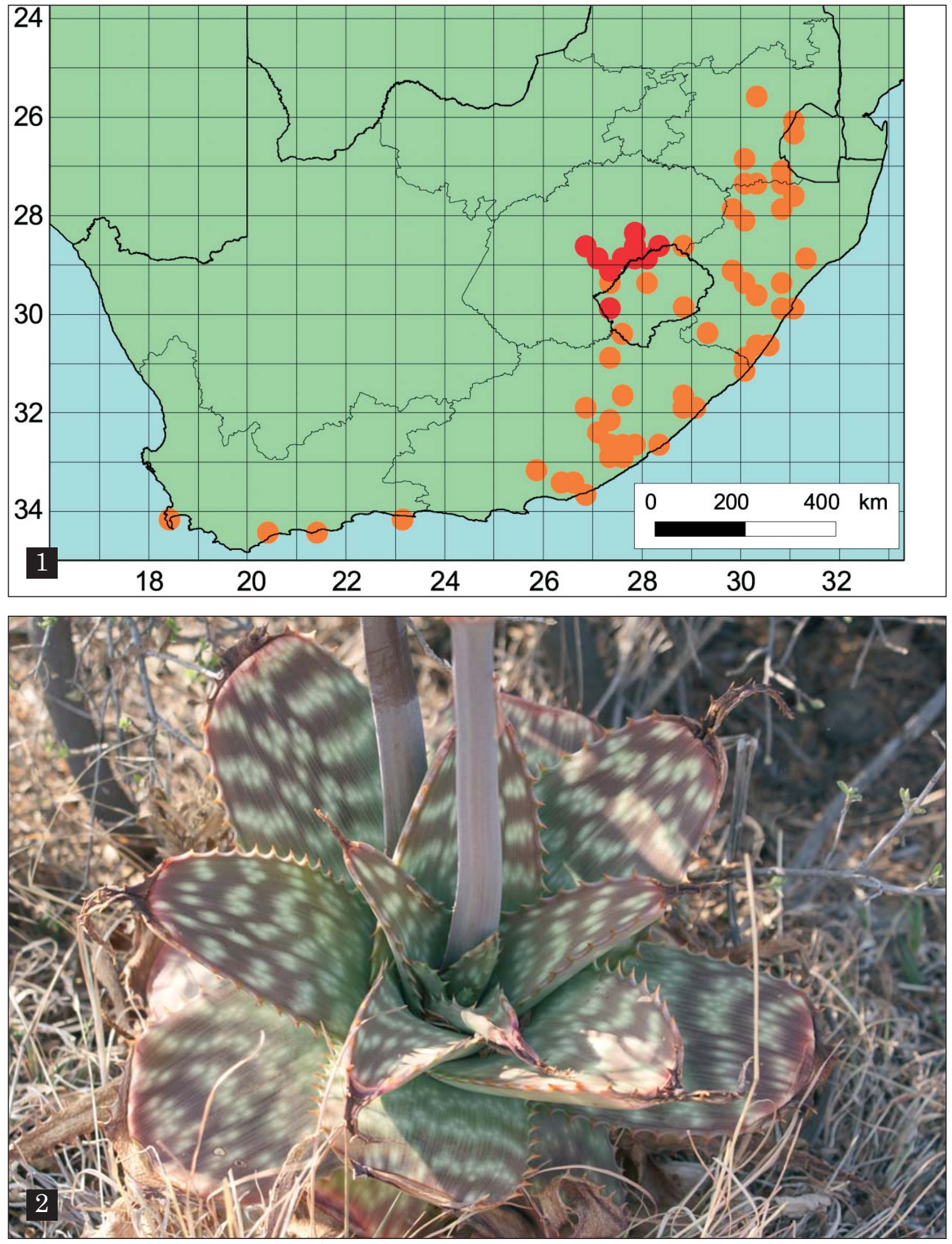

Figure 1. Known distribution of Aloe maculata subsp. maculata [orange] and A. maculata subsp. ficksburgensis [red] (based on specimens housed at PRE). Figure 2. Close-up of a rosette of A. maculata subsp. ficksburgensis near Winburg, central Free State. Photo: Gideon Smith. 
used by him for what is today regarded as A. maculata. This is a distinctive form of A. maculata which is in most respects a smaller plant. It differs from typical A. maculata in the ratios of bract length:pedicel length and pedicel length: perianth length, average raceme diameters, and raceme shape.

Glen \& Hardy (2000), however, regarded the var. ficksburgensis as a synonym of $A$. maculata, a suggestion followed by Klopper et al. (2009). Reynolds (1937) observed substantial variation within populations of what he described as a variety of $A$. maculata, noting that some were sufficiently distinct to suggest full species status. In the period since Reynolds made his field observations during 1935 and 1936, it has transpired that this taxon is of very limited range, growing largely allopatric with the typical variety. When this distributional character is considered together with the morphological differences (see under diagnostic characters), it is evident that this entity justifies subspecies status. Accordingly, we here resurrect the concept of var. ficksburgensis at subspecific level and make the new combination under Aloe maculata.

In their update of Harding's (1979) checklist to the aloes of the world, Richards \& Ellert (1999) mention a new combination Aloe maculata var. ficksburgensis (Reynolds) Dandy and attribute this to Dandy (1970). However, Dandy (1970) did not definitely associate the epithet 'ficksburgensis' with Aloe maculata, but merely indicated this older name to have priority over A. saponaria. Furthermore, Richards \& Ellert (1999) did not clearly indicate Aloe saponaria var. ficksburgensis Reynolds as the basionym, nor did they provide full and direct reference to its place of valid publication. Therefore, according to Articles 33.1 and 33.4 of the International Code of Botanical Nomenclature (McNeill et al., 2006) this combination was not validly published by Dandy (1970) nor by Richards \& Ellert (1999), and is thus listed here as an invalid name and synonym of the new combination.

\section{Taxonomy and nomenclature}

Aloe maculata All. subsp. ficksburgensis (Reynolds) Gideon F.Sm. \& Figueiredo comb. et stat. nov.

Basionym: Aloe saponaria (Aiton) Haw. var. ficksburgensis Reynolds in J. S. Afr. Bot. 3: 148 (1937). Aloe maculata All. var. ficksburgensis (Reynolds) Dandy in Richards \& Ellert: 101 (1999), nom. inval.

Type: Free State, northwestern slopes of sandstone hills at Molenspruit, 4 miles south of
Ficksburg, 6 September 1936, G.W. Reynolds 2087 (PRE, holo.!; BOL, iso.!).

Flowering time: August to September.

Etymology: ficksburgensis, for the occurrence near Ficksburg in the Free State Province, South Africa.

Aloe maculata All. in Auctarium ad synopsin methodicam stirpium horti regii Taurinensis: 65 (1773) subsp. maculata

Lectotype: Aloe Africana caulscens foliis spinosis maculates ab utraque parte albicantibus notates J.Commelijn, Horti medici Amstelaedamensis 2: 9, t. 5 (1701) [designated by Guglielmone et al. (2009)]. For a complete list of synonyms see Grace $e t a l$. (2011).

Flowering time: varies considerably throughout its distribution range, forms flowering throughout the year, with peaks from June to September in the north of its range and December to January in the south.

Etymology: maculata, for the spotted leaves, from the Latin 'maculatus' (spotted).

\section{Diagnostic characters of Aloe maculata subsp. ficksburgensis}

Aloe maculata subsp. ficksburgensis is in most respects a smaller plant than typical $A$. maculata. Its racemes are more broadly conical or roundtopped, bearing pink, yellow, orange or reddish flowers. On average, the racemes of $A$. maculata subsp. ficksburgensis are only $8 \mathrm{~cm}$ in diameter relative to those of $A$. maculata subsp. maculata which usually fall in the range 10-15 cm diameter. In typical A. maculata, floral bracts are mostly one quarter to half the length of their pedicels, whereas in the subsp. ficksburgensis they are as long as or slightly longer than their pedicels. The pedicels of subsp. ficksburgensis are shorter than those of subsp. maculata $[25 \mathrm{~mm}$ against $35-50(-70) \mathrm{mm}$ ] which partly accounts for this discordant bract:pedicel relationship. In the typical subspecies the flowers are usually as long as or shorter than their pedicels whereas in subsp. ficksburgensis the flowers are always longer (Reynolds, 1937).

The inflorescence branching pattern was not highlighted by Reynolds $(1937,1950)$ as diagnostic. There is nonetheless a difference in this character: the inflorescences of subsp. maculata are usually 4-8-branched, whereas those of subsp. ficksburgensis tend to be simple or with up to two branches. This is a valuable additional 

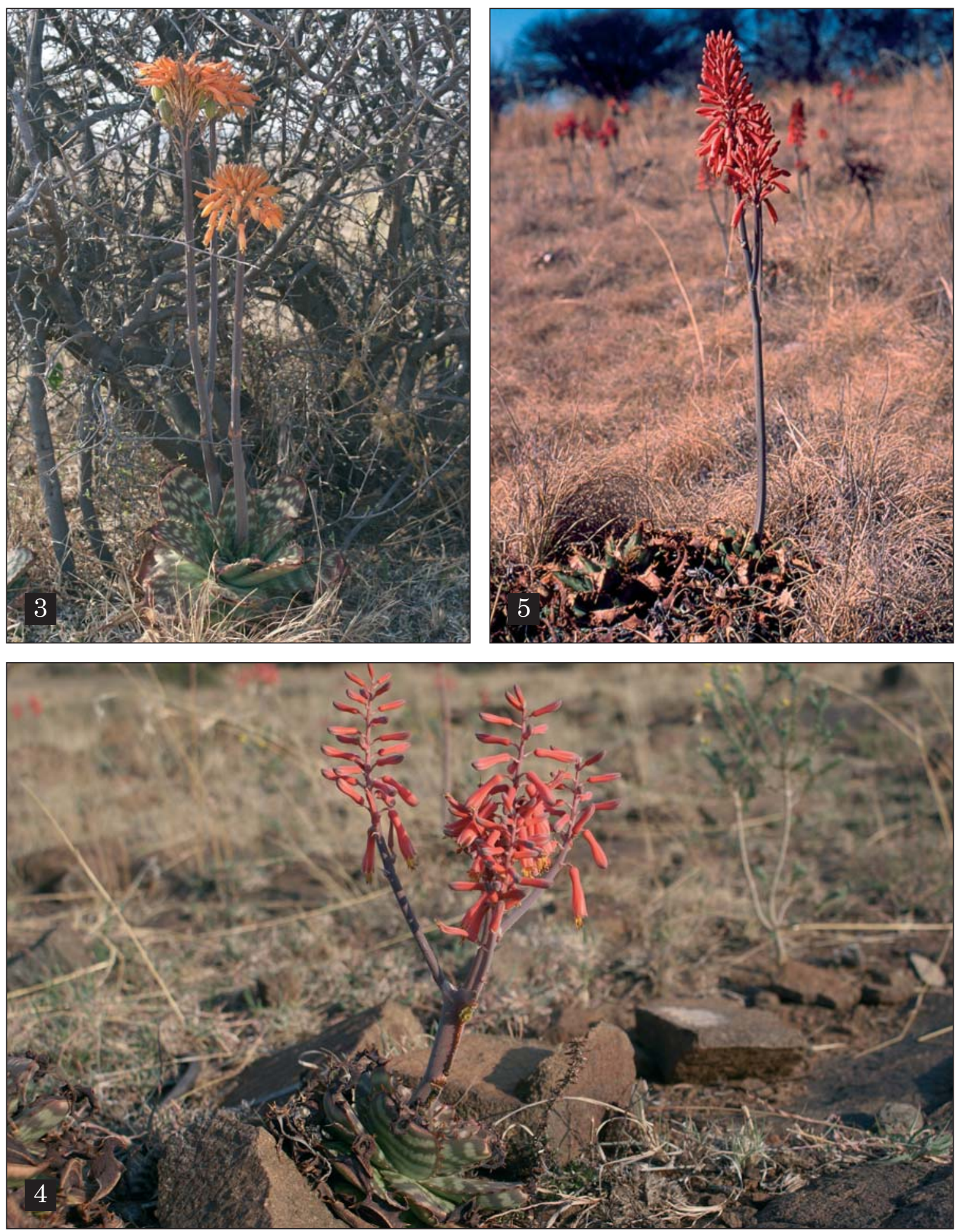

Figure 3. Aloe maculata subsp. ficksburgensis near Winburg, central Free State. Figure 4. Aloe grandidentata co-occurs with A. maculata subsp. ficksburgensis near Winburg, central Free State. Figure 5. Aloe davyana enters the Free State province in the north. This population was found halfway between Johannesburg and Kroonstad, near Koppies. Photos: Gideon Smith. 
Table 1. Differences between the four maculate Aloe taxa occurring in the Free State.

\begin{tabular}{|c|c|c|c|c|}
\hline Character & $\begin{array}{l}\text { A. maculata subsp. } \\
\text { maculata }\end{array}$ & $\begin{array}{l}\text { A. maculata subsp. } \\
\text { ficksburgensis }\end{array}$ & A. grandidentata & A. davyana \\
\hline Inflorescence & $\begin{array}{l}0.4-1.0 \mathrm{~m} \text { high, } 4-8- \\
\text { branched from about } \\
\text { middle }\end{array}$ & $\begin{array}{l} \pm 0.5 \mathrm{~m} \text { high, simple } \\
\text { or with } 1-2 \text { branches } \\
\text { from middle or lower }\end{array}$ & $\begin{array}{l} \pm 0.9 \mathrm{~m} \text { high, } 4-7- \\
\text { branched above } \\
\text { middle }\end{array}$ & $\begin{array}{l}0.6-1.0 \mathrm{~m} \text { high, } 3-5- \\
\text { branched from below } \\
\text { middle }\end{array}$ \\
\hline Raceme & $\begin{array}{l}\text { capitate-corymbose, } \\
\text { dense, } 10-15 \mathrm{~cm} \\
\text { diam. }\end{array}$ & $\begin{array}{l}\text { capitate, with } \\
\text { rounded or broadly } \\
\text { conical apex, dense, } \\
8 \mathrm{~cm} \text { diam. }\end{array}$ & $\begin{array}{l}\text { cylindric, slightly } \\
\text { acuminate, lax, } \\
4.0-5.5 \mathrm{~cm} \text { diam. }\end{array}$ & $\begin{array}{l}\text { broadly conical, } \\
\text { apically dense, } \\
\text { basally laxer, } \\
7-8 \mathrm{~cm} \text { diam. }\end{array}$ \\
\hline Flowers & $\begin{array}{l}\text { usually pink to } \\
\text { orange, sometimes } \\
\text { yellow or red, } \\
35-45 \mathrm{~mm} \text { long, } \\
\text { distinctly swollen } \\
\text { basally, slightly } \\
\text { decurved }\end{array}$ & $\begin{array}{l}\text { usually orange or } \\
\text { yellow, sometimes } \\
\text { orange or reddish, } \\
30-40 \text { mm long, } \\
\text { swollen basally, } \\
\text { slightly decurved }\end{array}$ & $\begin{array}{l}\text { dull red, } 28-30 \mathrm{~mm} \\
\text { long, not or very } \\
\text { slightly narrowed } \\
\text { above ovary, } \\
\text { distinctly clavate }\end{array}$ & $\begin{array}{l}\text { pale pink to dull red, } \\
\text { greenish to greyish } \\
\text { striped, } 32-35 \mathrm{~mm} \\
\text { long, distinctly } \\
\text { swollen basally, } \\
\text { slightly decurved }\end{array}$ \\
\hline Floral bracts & 12-23 mm long & $\pm 25 \mathrm{~mm}$ long & $10-15 \mathrm{~mm}$ long & $20-25 \mathrm{~mm}$ long \\
\hline Pedicels & $35-50 \mathrm{~mm}$ long & $\pm 25 \mathrm{~mm}$ long & $10-15 \mathrm{~mm}$ long & $20-25 \mathrm{~mm}$ long \\
\hline $\begin{array}{l}\text { Leaf (upper } \\
\text { surface) }\end{array}$ & $\begin{array}{l}\text { pale to darker green, } \\
\text { with numerous, dull, } \\
\text { white spots in } \\
\text { irregular broken, } \\
\text { wavy, transverse } \\
\text { bands }\end{array}$ & $\begin{array}{l}\text { greenish near base, } \\
\text { brownish upwards, } \\
\text { with numerous spots } \\
\text { confluent in } \\
\text { undulating, } \\
\text { interrupted bands }\end{array}$ & $\begin{array}{l}\text { brownish green, with } \\
\text { numerous dull, } \\
\text { white, oblong spots, } \\
\text { usually arranged in } \\
\text { interrupted, } \\
\text { transverse bands }\end{array}$ & $\begin{array}{l}\text { green, with numerous } \\
\text { oblong, white spots, } \\
\text { sometimes arranged } \\
\text { in interrupted, wavy } \\
\text { transverse bands }\end{array}$ \\
\hline $\begin{array}{l}\text { Leaf (lower } \\
\text { surface) }\end{array}$ & $\begin{array}{l}\text { paler green, } \\
\text { obscurely lineate and } \\
\text { usually without spots }\end{array}$ & $\begin{array}{l}\text { paler green, usually } \\
\text { without spots, some- } \\
\text { times with obscure } \\
\text { immersed spots }\end{array}$ & $\begin{array}{l}\text { more prominently } \\
\text { marked }\end{array}$ & $\begin{array}{l}\text { pale glaucous green, } \\
\text { obscurely lineate, } \\
\text { without spots }\end{array}$ \\
\hline $\begin{array}{l}\text { Distribution } \\
\text { in Free State } \\
\text { and Lesotho }\end{array}$ & $\begin{array}{l}\text { northeastern Free } \\
\text { State, Lesotho }\end{array}$ & $\begin{array}{l}\text { central and eastern } \\
\text { Free State, Lesotho }\end{array}$ & $\begin{array}{l}\text { central, southern } \\
\text { and western Free } \\
\text { State }\end{array}$ & northern Free State \\
\hline $\begin{array}{l}\text { Flowering } \\
\text { time }\end{array}$ & $\begin{array}{l}\text { June-September in } \\
\text { the north, } \\
\text { December-January } \\
\text { in the south }\end{array}$ & August-September & August-September & May-July \\
\hline
\end{tabular}

macro-morphological character to assist with delimiting the two subspecies of $A$. maculata.

\section{Distribution range of Aloe maculata subsp. ficksburgensis}

While A. maculata subsp. maculata is the most widely distributed of the maculate aloes in southern Africa, A. maculata subsp. ficksburgensis is restricted to the eastern parts of the Free State province of South Africa and the western parts of Lesotho (Figure 1). The apparent slight overlap in the general distribution ranges of the subspecies does not detract from them being distinguished at subspecific level as the two subspecies have not been recorded from the same locality.
During a recent field trip, plants of typical A. maculata subsp. ficksburgensis were recorded from near Winburg in the Free State, which is situated about $100 \mathrm{~km}$ northeast of Bloemfontein, the provincial capital. In all characters plants were found to coincide with those of specimens referable to the subsp. ficksburgensis. Furthermore, the flowers of specimens found near Winburg are a uniform, bright orange colour, with a slight waxy bloom and bracts are as long as or slightly longer than their pedicels (Figures $2 \& 3$ ). This recent collection represents a range extension of $\pm 80 \mathrm{~km}$ to the west of existing records for A. maculata subsp. ficksburgensis in the Free State (Figure 1). The climate in the central 
Free State is considerably harsher than in most other parts of southern Africa where typical A. maculata has been recorded, especially in terms of winter minimum temperatures (Mucina \& Rutherford, 2006).

In the vicinity of Winburg A. maculata subsp. ficksburgensis co-occurs with $A$. grandidentata Salm-Dyck (Figure 4), of which the distinctly clavate flowers lack the basal swelling so characteristic of the group of spotted aloes comprising Section Pictae Salm-Dyck. The fourth, and only other maculate aloe known from the Free State, Aloe davyana Schönland, is recorded only from the northern extremes of the province, and has dusty pink to reddish flowers lined with white (Figure 5) (see Table 1).

Other specimens examined for Aloe maculata subsp. ficksburgensis

FREE STATE.-2826 (Brandfort): About five kilometers south of Winburg, on the southern side of the road leading to the N1 highway, $(-D B)$, in rocky grassland vegetation, $1391 \mathrm{~m}, 4$ September 2009, G.F. Smith \& E. Figueiredo 16 (PRE). 2827 (Senekal): Between Paul Roux and Senekal, (-BD), 29 September 1986, P.C. Zietsman 59 (NMB, PRE); Senekal Dist., Farm Franshoek, (-DB), 3 July 1973, N.A. Ferreira 5 (NMB); Korannaberg, (-CC), 15 April 1987, P.J. du Preez 687 (BLFU); Ficksburg Dist., Molenspruit, 4 miles west of Ficksburg, (-DD), 24 September 1935, G.W. Reynolds 1573 (PRE); 6 September 1936, G.W. Reynolds 2085 \& 2086 (PRE). 2828 (Bethlehem): Clarens Dist., Clifton, (-CB), 7 September 1988, T. Saaiman 187 \& 188 (NMB, PRE). 2927 (Maseru): Ladybrand, on hills 2 miles south of Ladybrand, (-AB), 25 September 1935, G.W. Reynolds 1575 (PRE); 2 miles south of Ladybrand in sandstone hill, (-AB), 5 August 1936, G.W. Reynolds 2084 (PRE); 6 miles southwest of Ladybrand (-AB), 19 August 1941, L.K.A. Chippindall 304 (PRE).

LESOTHO._-2828 (Bethlehem): Leribe, (-CC), 1913, A. Dieterlen 337 (PRE); 3 miles south of Leribe, (-CC), 24 September 1935, G.W. Reynolds 1574 (PRE); 8 miles northeast of Ficksburg O.F.S., east of the Caledon River, $(-\mathrm{CC}), 8$ September 1936, G.W. Reynolds 2089 (PRE). 2927 (Maseru): Likhoele, mountain slopes (-CD), October + November 1915, A. Dieterlen 127 (PRE).

\section{Acknowledgements}

The authors would like to thank: the curators of the following herbaria for providing access to their collections: BLFU, NBG, NMB, PRE; Dr Hugh Glen of the South African National Biodiversity
Institute for nomenclatural advice; an anonymous referee for suggesting improvements to the manuscript.

\section{References}

CArter, S. (1996). New aloe taxa in the Flora Zambesiaca area. Kew Bull. 51: 777-785.

Carter, S. (2001). Aloaceae. 3. Aloe L. In G.V. Pope, Flora zambesiaca 12, 3: 48-98. Royal Botanic Gardens, Kew.

DANDY, J.E. (1970). Annotated list of the new names published in Allioni's Auctarium ad synopsin methodicam stirpium horti regii Taurinensis. Taxon 19: 617-626.

Glen, H.F. \& HARDY, D.S. (2000). Aloaceae (First part): Aloe. In G. Germishuizen, Flora of southern Africa, vol. 5, part 1, fascicle 1: 1159. National Botanical Institute, Pretoria.

Grace, O.M., Klopper, R.R., Figueiredo, E. \& Smith, G.F. (2011). The aloe names book. Strelitzia 28. South African National Biodiversity Institute, Pretoria and the Royal Botanic Gardens, Kew, London.

Guglielmone, L., Gallo, L., Meregalli, M., Smith, G.F. \& Figueiredo, E. (2009). Allioni's Aloe L. (Asphodelaceae) names: Nomenclature and typification. Bothalia 39: 177-183.

HARDING, T.B. (1979). Aloes of the world: a checklist, index and code. Excelsa 9: 57-94.

Klopper, R.R., Retief, E. \& Sмith, G.F. (2009). The genus Aloe L. (Asphodelaceae: Alooideae) in the Free State Province of South Africa. Haseltonia 15: 41-52.

McNeill, J., Barrie, F. R., Burdet, H. M., Demoulin, V., Hawksworth, D. L., Marhold, K., Nicolson, D. H., Prado, J., Silva, P. C., Skog, J. E., Wiersema, J. H. \& Turland, N. J. (2006). International Code of Botanical Nomenclature (Vienna Code) adopted by the Seventeenth International Botanical Congress, Vienna, Austria, July 2005. Reg. Veg. 146: 1-568. Gantner Verlag, Liechtenstein.

MucinA, L. \& Rutherford, M.C. (eds.). (2006). The vegetation of South Africa, Lesotho and Swaziland. Strelitzia 19. South African National Biodiversity Institute, Pretoria.

Reynolds, G.W. (1937). A new Aloe from SouthWest Africa, together with new varieties from the Transvaal and Orange Free State. J. $S$. Afr. Bot. 3: 143-150.

REYNOLDS, G.W. (1950). The aloes of South Africa. The aloes of South Africa book fund, Johannesburg.

RichaRds, D.J. \& ElLERT, A.F.N. (1999). A second update to T.B.C. Harding's 'Aloes of the world: a checklist, index and code' as published in Excelsa no. 9. Excelsa 19: 95-105. 